\title{
Migration and Fate of Acid Mine Drainage Pollutants in Calcareous Soil
}

\author{
Fenwu Liu ${ }^{1, *,+}{ }^{+}$Xingxing Qiao ${ }^{1,+}{ }^{\dagger}$ Lixiang Zhou ${ }^{2}$ and Jian Zhang ${ }^{1}$ \\ 1 Environmental Engineering Laboratory, College of Resource and Environment, \\ Shanxi Agricultural University, Taigu 030801, China; qiaoxingxing@stu.sxau.edu.cn (X.Q.); \\ zhangjian@sxau.edu.cn (J.Z.) \\ 2 Department of Environmental Engineering, College of Resources and Environmental Sciences, \\ Nanjing Agricultural University, Nanjing 210095, China; lxzhou@njau.edu.cn \\ * Correspondence: liufenwu@sxau.edu.cn; Tel./Fax: +86-354-6288399 \\ + Both authors contributed equally to this work.
}

Received: 6 July 2018; Accepted: 9 August 2018; Published: 16 August 2018

\begin{abstract}
As a major province of mineral resources in China, Shanxi currently has 6000 mines of various types, and acid mine drainage (AMD) is a major pollutant from the mining industry. Calcareous soil is dominant in western North China (including the Shanxi Province), therefore, clarifying the migration behavior of the main AMD pollutants $\left(\mathrm{H}^{+}, \mathrm{S}, \mathrm{Fe}\right.$, heavy metals) in calcareous soil is essential for remediating AMD-contaminated soil in North China. In this study, the migration behavior of the main pollutants from AMD in calcareous soil was investigated using soil columns containing $20 \mathrm{~cm}$ of surficial soil to which different volumes of simulated AMD were added in 20 applications. Filtrate that was discharged from the soil columns and the soil samples from the columns were analyzed. Almost all of the Fe ions (>99\%) from the AMD were intercepted in the $0-20 \mathrm{~cm}$ depth of the soil. Although $>80 \%$ of $\mathrm{SO}_{4}{ }^{2-}$ was retained, the retention efficiency of the soil for $\mathrm{SO}_{4}{ }^{2-}$ was lower than it was for $\mathrm{Fe}$. $\mathrm{Cu}$, as a representative of heavy metals that are contained in AMD, was nearly totally retained by the calcareous soil. However, $\mathrm{Cu}$ had a tendency to migrate downward with the gradual acidification of the upper soil. In addition, $\mathrm{CaCO}_{3}$ was transformed into $\mathrm{CaSO}_{4}$ in AMD-contaminated soil. The outcomes of this study are valuable for understanding the pollution of calcareous soil by AMD and can provide key parameters for remediating AMD-contaminated soil.
\end{abstract}

Keywords: acid mine drainage; Fe; S; calcareous soil; pollutant migration behavior

\section{Introduction}

In China, the mining industry is an important pillar industry that provides essential energy and other resources for national economic development [1]. There were more than 63,433 metal and non-metal mines in China in 2015, and the quantity of non-metal mines exceeds 56,600 . What is more, the number of coal mines in China exceeds 15,000 [2]. As a major province of mineral resources in China, Shanxi currently (2018) has 6000 mines of different types. Notably, the rapid development of the coal mining industry in the Shanxi Province has had great effects on the province's economic development [3]. However, mining activity is a double-edged sword for society. On the one hand, the industry produces economic benefits, however on the other hand, it causes serious contamination to the environment [4]. The environmental issues around mining areas are primarily related to mining-related surface disturbance [5], tailings waste pile production [6], dust pollution [7], and acid mine drainage (AMD) [8].

The oxidation of sulfide minerals that are associated with metal ore and coal ore is the main cause of AMD from mining activity [9]. Pyrite $\left(\mathrm{FeS}_{2}\right)$ is the most common sulfide mineral that is responsible 
for the occurrence of AMD [10]. Therefore, AMD is very acidic $(\mathrm{pH}<3.0)$ and normally contains a high amount of iron, sulfate, and a certain amount of heavy metals [11,12]. Inadequately treated AMD is a very widespread environmental problem that directly affects the healthy development of the mining industry [13]. Many researchers have studied environmental problems in soil and aquatic ecosystems that have arisen from acid mine drainage in China and elsewhere [5,14-18]. In fact, soil that has been polluted by iron and sulfate has attracted extensive attention around the world. For example, iron and sulfate transformations in acid sulfate soils is a hot issue in the environmental field in Australia $[19,20]$.

China is the most populous country in the world. By the end of 2015, China's population reached 1.37 billion [21], accounting for $18.7 \%$ of the total world population. In addition, China is a traditionally agricultural country [22]. Therefore, the issue of cultivated land quality has always been very topical in China [23]. Unfortunately, in China, some farmland that is surrounded by mining areas has been severely polluted by AMD $[3,5,14,24]$. Therefore, it is important to accurately identify the migration behavior of AMD pollutants in Chinese soils.

In fact, many studies in the last decade have focused on the migration behavior of AMD pollutants in red soil with a $\mathrm{pH}<7.00$, located in South China [24-26]. Li et al. [25] found that in the $0-15 \mathrm{~cm}$ surface horizon soils that were collected from the Dabaoshan Mountain of the Guangdong Province in South China, the total contents of $\mathrm{Cu}, \mathrm{Pb}, \mathrm{Zn}$, and $\mathrm{Cd}$ were significantly higher in AMD-polluted soils by 17 times, 7 times, 5 times, and 2.5 times, respectively, compared to the unpolluted soils. Yang et al. [26] noted that a significant amount of $\mathrm{SO}_{4}{ }^{2-}$ was adsorbed by $\mathrm{Fe} / \mathrm{Al}$ oxides and fine clays, and that a large amount of Fe existed as amorphous Fe oxide at the $20-30 \mathrm{~cm}$ mid-depth layer in AMD-contaminated soils along the Hengshi River of the Dabaoshan sulfide mining area, South China. In addition, Wang et al. [24] reported that AMD irrigation changed the composition and the diversity of the bacterial community in a paddy soil located in the Guangdong Province, and increased the abundance of sulfate-reducing bacteria in the soil.

Shanxi, a province in the northern part of China, is rich in mineral resources, especially coal resources [3]. In addition, the production of AMD as a result of mining activity in the Shanxi Province has been reported by a large number of researchers. Zhao et al. [27] investigated the geochemical characteristics of rare earth elements in AMD from the Sitai coal mine in the Shanxi Province and found that the sulfate complexes and free metal species in the AMD were dominant rare earth element species. Gao et al. [28] isolated an iron-oxidizing bacterium from AMD that was produced by the Zhongtiaoshan copper mine in the Shanxi Province. Notably, the dominant soil type in western North China, including the Shanxi Province, is calcareous with a high proportion of calcium carbonate $\left(\mathrm{CaCO}_{3}\right)$ and a $\mathrm{pH}$ level often exceeding 8.0 [28-30]. Thus, the soil in North China has totally different characteristics from the red soil in South China (including the Guangdong Province). Unfortunately, the migration behavior of AMD pollutants in calcareous soil has never been reported. The clarification of this scientific problem is of great theoretical and practical significance for understanding the migration behavior of AMD pollutants in soil in northern China. Studying the migration of AMD pollutants in calcareous soil can help close up the data gap regarding soil pollution by AMD in China, especially in North China.

In view of this, the main objective of this study was to explore the migration behavior of key AMD pollutants $\left(\mathrm{H}^{+}, \mathrm{Fe}^{3+}, \mathrm{SO}_{4}{ }^{2-}\right.$, and heavy metal ions, with $\mathrm{Cu}$ as an example) in calcareous soils using experimental soil columns.

\section{Materials and Methods}

\subsection{Preparation of Simulated Acid Mine Drainage}

Simulated AMD for the small-scale soil column experiment was prepared in 20 batch applications as follows. First, $15 \mathrm{~mL}$ of $A$. ferrooxidans LX5 inoculum [2] was added into each of a series of 250-mL Erlenmeyer flasks, each containing $50 \mathrm{~mL}$ of modified $9 \mathrm{~K}$ liquid medium stock solution and $85 \mathrm{~mL}$ of deionized water. The inorganic salt concentrations of the modified $9 \mathrm{~K}$ liquid medium (comprised of 
$0.0168 \mathrm{~g}$ of $\mathrm{Ca}\left(\mathrm{NO}_{3}\right)_{2}, 0.058 \mathrm{~g}$ of $\mathrm{K}_{2} \mathrm{HPO}_{4}, 0.119 \mathrm{~g}$ of $\mathrm{KCl}, 0.583 \mathrm{~g}$ of $\mathrm{MgSO}_{4} \cdot 7 \mathrm{H}_{2} \mathrm{O}, 3.5 \mathrm{~g}$ of $\left(\mathrm{NH}_{4}\right)_{2} \mathrm{SO}_{4}$, $44.2 \mathrm{~g}$ of $\mathrm{FeSO}_{4} \cdot 7 \mathrm{H}_{2} \mathrm{O}$ in $1 \mathrm{~L}$ of deionized water, adjusted to $\mathrm{pH} 2.50$ ) were increased three times in the stock solution. Then, the mixtures in the flasks were adjusted to $\mathrm{pH} \sim 2.50$ and were incubated at $18-28{ }^{\circ} \mathrm{C}$ while being shaken at $150-180 \mathrm{rpm}$ for $3-7$ days until the ferrous ions were completely bio-oxidized. After incubation, the solution in each flask was filtered through quantitative filter paper to remove iron-based precipitate. The filtrate that was obtained in this process was considered to be the simulated AMD and was immediately stored at $4{ }^{\circ} \mathrm{C}$ for $2-3$ days until use. During this period, the content of $\mathrm{Fe}, \mathrm{SO}_{4}{ }^{2-}$, and the other measured elements had not been changed before or after being stored. Then, $0.0977 \mathrm{~g}$ of $\mathrm{CuSO}_{4} \cdot 5 \mathrm{H}_{2} \mathrm{O}$ was dissolved in the $500 \mathrm{~mL}$ of simulated AMD to yield $\mathrm{Cu}^{2+}$ concentration $\sim 50 \mathrm{mg} / \mathrm{L}$. The $\mathrm{pH}$, total Fe concentration, and $\mathrm{SO}_{4}{ }^{2-}$ concentration varied among the batch applications of the simulated AMD because the culture condition and the water evaporation degree were different during the preparation process. The $\mathrm{pH}$ of the simulated AMD for the soil column experiment varied from 2.22 to 2.49 , the total Fe concentration varied from $7464.61 \mathrm{mg} / \mathrm{L}$ to $9328.02 \mathrm{mg} / \mathrm{L}$, and the $\mathrm{SO}_{4}{ }^{2-}$ concentration varied from $19,542.25 \mathrm{mg} / \mathrm{L}$ to $35,035.21 \mathrm{mg} / \mathrm{L}$.

\subsection{Soil Column Experiment}

Calcareous brown soil was collected from a site $\left(112^{\circ} 34^{\prime} 28^{\prime \prime} \mathrm{E}, 37^{\circ} 25^{\prime} 30^{\prime \prime} \mathrm{N}\right)$ in Shanxi Agricultural University, Taigu, Shanxi Province, China. Ten subsamples were collected within $25 \mathrm{~m}^{2}$ using the plum blossom method from the surface soil layer $(0-20 \mathrm{~cm})$ in the sampling plot and were combined into a composite soil sample $(\sim 10 \mathrm{~kg})$. The moisture content in situ soil was $11.64 \%$, which can be calculated through the difference between the weight of the original collected soil and the weight of the $105{ }^{\circ} \mathrm{C}$-dried soil. Some soil was air-dried and was passed through a 1-mm sieve to generate the samples for $\mathrm{pH}$ determination. Some soil was dried at $105^{\circ} \mathrm{C}$, was passed through a $0.15-\mathrm{mm}$ sieve, and was analyzed for $\mathrm{Fe}, \mathrm{S}, \mathrm{Cu}$, and $\mathrm{Ca}$ content. These analyses showed that the $\mathrm{pH}$ of the selected soil was 8.24 , and the weight percentages of $\mathrm{Fe}, \mathrm{S}, \mathrm{Cu}$, and Ca were $2.99 \%, 0.0337 \%, 0.0029 \%$, and $5.35 \%$, respectively. In addition, the clay fraction content in the tested soil was $19.9 \%$.

Fifteen glass columns (with a $25 \mathrm{~cm}$ length and $4.7 \mathrm{~cm}$ internal diameter) were uniformly packed to a depth of $20 \mathrm{~cm}$ with collected soil. The weight and density of the soil in each glass tube was $\sim 380 \mathrm{~g}$ and $\sim 1.042 \mathrm{~g} / \mathrm{cm}^{3}$. Four layers of gauze were placed in the bottom of each soil column to prevent the loss of soil particles during the experiment. The pre-experiment results showed that this gauze application had no impact on the efficiency of the contaminant removal. $\mathrm{Cu}$ is one of the most important heavy metals in acid mine drainage in the Shanxi area. Therefore, the migration behavior of $\mathrm{Cu}$ from $\mathrm{AMD}$ in the calcareous soil was investigated in this study. Five treatments were conducted. The $22 \mathrm{~mL}$ (for treatment 1), $44 \mathrm{~mL}$ (for treatment 2), $66 \mathrm{~mL}$ (for treatment 3), $88 \mathrm{~mL}$ (for treatment 4), and $110 \mathrm{~mL}$ (for treatment 5) of the simulated AMD were added to the upper end of the soil columns during each application. The AMD properties that were applied to treatments 1 to 5 were consistent for the same application. All of the treatments were designed with three replicates. In fact, our team used the soil column (with a $20 \mathrm{~cm}$ effective length and $16 \mathrm{~cm}$ internal diameter) to carry out the related research pre-experiment with the addition of $0.25 \mathrm{~L}$ of stimulated AMD before carrying out this study. From the pre-experiment results, it was found that the AMD pollutants (such as $\mathrm{Fe}, \mathrm{SO}_{4}{ }^{2-}, \mathrm{Cu}$ ) were mainly intercepted in the soil. Therefore, on the basis of the pre-experiment results, this study sought to further investigate the migration of AMD pollutants in the surface $0-20 \mathrm{~cm}$ soil. The parameter of $22 \mathrm{~mL}$ of stimulated AMD came from the relevant parameters in the pre-experiment. Based on the selected $22 \mathrm{~mL}$, the $44 \mathrm{~mL}, 66 \mathrm{~mL}, 88 \mathrm{~mL}$, and $110 \mathrm{~mL}$ in this study were set according to equal difference. A total of 20 batches of applications of AMD were added to each soil column over 132 days. A schematic diagram of the reaction columns is shown in Figure 1. All of the soil columns were sealed and stored at $4{ }^{\circ} \mathrm{C}$ during days $78-108$ because of the winter vacation. After each application of AMD, the $\mathrm{pH}$ of the filtrate that was collected from the bottom of each soil column (if any) was measured. In addition, $1 \mathrm{~mL}$ of filtrate was passed through a $0.22-\mu \mathrm{m}$ membrane filter and the total $\mathrm{Fe}$ and $\mathrm{SO}_{4}{ }^{2-}$ concentrations in the filtrate were analyzed. 


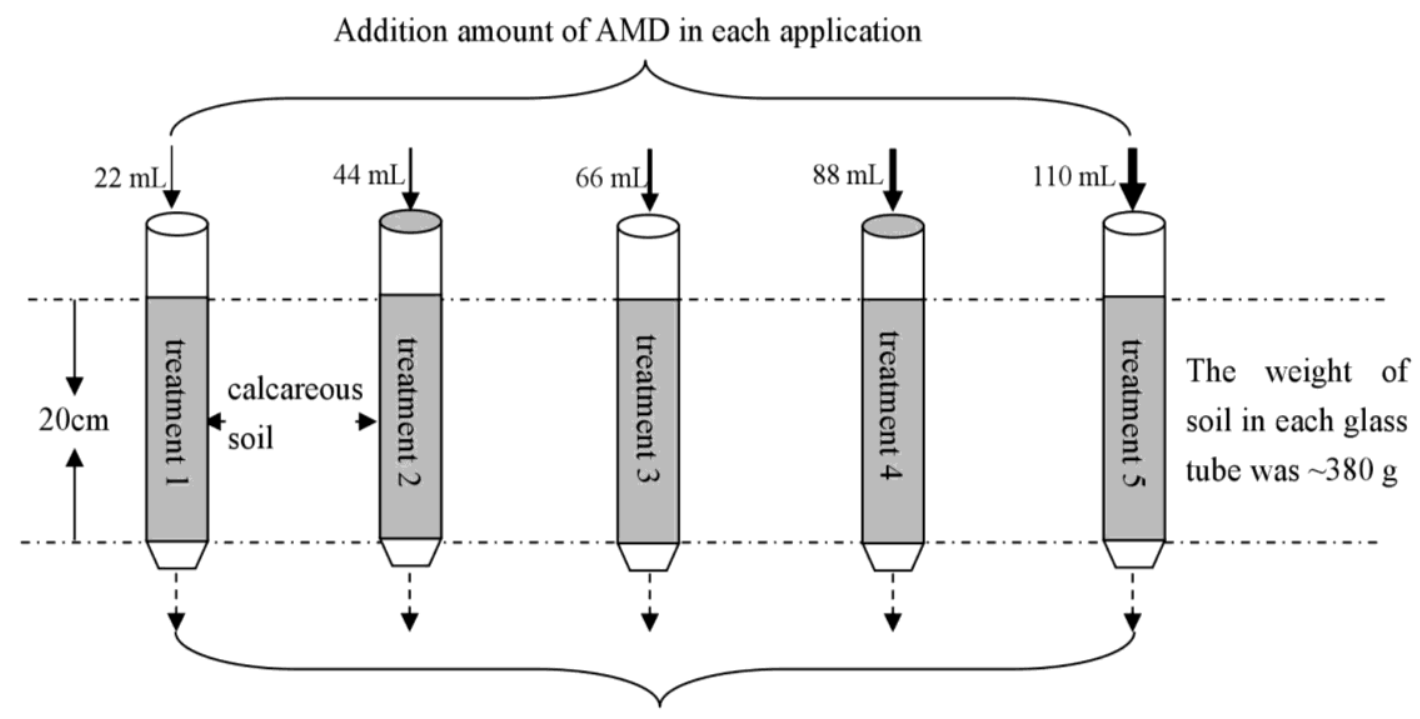

Filtrate collected from the bottom of each soil column

Figure 1. Schematic diagram of reaction columns (total of 20 batches of applications of AMD were added to each soil column over 132 days).

Among the 20 batches of applications of AMD, six batch applications (on days 25, 39, 58, 72, 122 , and 132) were randomly selected for the analysis of $\mathrm{Cu}^{2+}$ concentrations in the filtrate. The $\mathrm{Cu}^{2+}$ removal efficiency of the soil was calculated based on the difference between the $\mathrm{Cu}^{2+}$ concentrations in the filtrate and in the simulated AMD as applied. When all 20 batches of the AMD applications had been completed, the soil columns in treatments 1-5 were separated at the middle of the column and were marked as "soil ${ }_{0-10 \mathrm{~cm}}$ " and "soil $10-20 \mathrm{~cm}$ ". A series of $\mathrm{pH}$ analyses were conducted on the airdried soil from the two groups of the samples that were passed through a 1-mm sieve. In this study, the AMD addition amount was the minimum value $(22 \mathrm{~mL}$ for each application) in treatment 1 and the maximum value in treatment 5 (110 mL for each application). Soil samples from treatment 1 and treatment 5 were dried at $105^{\circ} \mathrm{C}$ and were passed through a 0.15 -mm sieve for analyses to determine the concentrations of $\mathrm{Fe}, \mathrm{S}, \mathrm{Cu}$, and $\mathrm{Ca}$, as well as soil morphology and soil mineralogy.

\subsection{Analytical Procedures}

The solution $\mathrm{pH}$ was measured using a pHS-3C model digital pH-meter [2] (Shanghai Yueping Scientific Instruments Co., Ltd., Shanghai, China). The total Fe concentration in the solution was determined using the 1,10-phenanthroline method [31]. The $\mathrm{SO}_{4}{ }^{2-}$ concentration was determined using the barium sulfate turbidimetric method [32]. The $\mathrm{Cu}^{2+}$ concentration in the solution was determined using an atomic absorption spectrophotometer [33] (6810, Shanghai Senpu Technology Co., Ltd., Shanghai, China). The $\mathrm{Cu}^{2+}$ retention efficiency of a soil column was calculated as: $\mathrm{Cu}^{2+}$ retention efficiency $(\%)=\left[\left(C_{0}-C_{t}\right) / C_{0}\right] \times 100 \%$ (where $C_{0}$ is the initial $\mathrm{Cu}^{2+}$ concentration and $C_{t}$ is the $\mathrm{Cu}^{2+}$ content in the filtrate from the soil columns in each application). The mineral phase or the morphology of the soil was determined by power X-ray diffraction (XRD) (MiniFlex II, Tokyo, Japan) using $\mathrm{CuK} \alpha$ radiation $(30 \mathrm{KV}, 15 \mathrm{~mA}$ ) or field-emission scanning electron microscopy (SEM) (JSM-7001F, Tokyo, Japan) [34]. The Fe and Ca contents in the soil were determined by X-ray fluorescence spectrometry (ZSX Primus II, Rigaku, Japan) [35]. The S content in the soil was determined using the combustion iodometric titration method [36]. In brief, the soil sample was placed in a tubular electric furnace at $1235-1300{ }^{\circ} \mathrm{C}$, and the $\mathrm{S}$ element was converted to sulfur dioxide. Then, sulfur dioxide was absorbed by the distilled water and was titrated with an iodine standard solution. During the titration process, starch was used as an indicator. 


\subsection{Statistical Analysis}

Data analysis was performed using Microsoft Excel ${ }^{\circledR} 2010$ (Microsoft Corporation, Redmond, WA, USA). All of the data points that are given in figures are mean values with their standard deviations to show their repeatability and reliability. All of the figures were drawn using Origin ${ }^{\circledR} 7.5$ software (OriginLab, Northampton, MA, USA).

\section{Results and Discussion}

\subsection{Acid Buffering Performance of Calcareous Soil against AMD Pollution}

The acid buffering performance of calcareous soil against AMD pollution was evaluated by analyzing the changes in the $\mathrm{pH}$ of the filtrate that was collected from the bottom of the different soil columns (Figure 2).

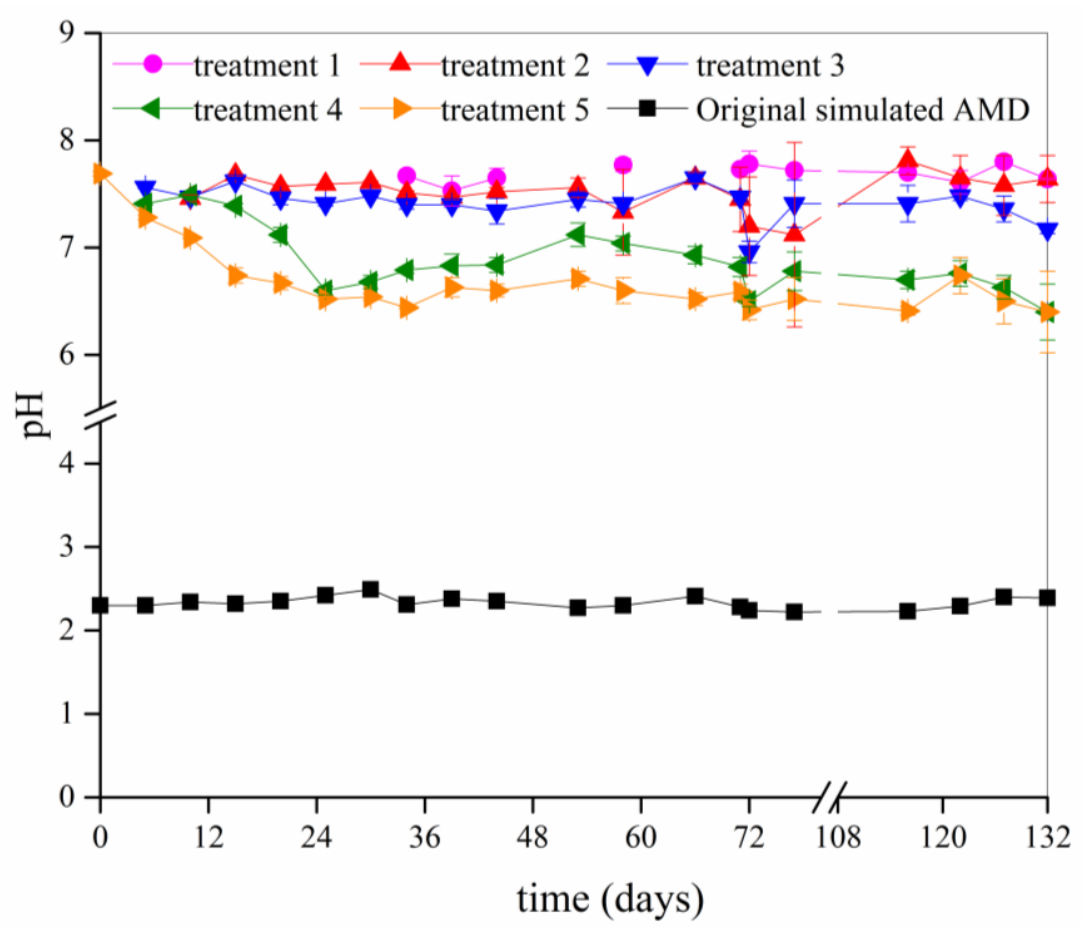

Figure 2. The $\mathrm{pH}$ of the filtrate that was collected from the bottom of the soil columns in the different treatments. (Treatments 1, 2, 3, 4, and 5 represent the addition of 22, 44, 66, 88, and $110 \mathrm{~mL}$, respectively, of simulated acid mine drainage (AMD) to the soil columns at each application).

In general, the maximum water-holding capacity for the calcareous brown soil in the Shanxi province ranges from $20 \%$ to $30 \%$ [37]. In this study, the initial soil moisture content (11.64\%) was below the soil's maximum water-holding capacity. The filtrate volume that was collected from the calcareous soil column in treatment 1 ( $22 \mathrm{~mL}$ AMD per application) was $<5 \mathrm{~mL}$ during the first 30 days because the soil moisture content during this time did not reach the soil's maximum water-holding capacity. The $\mathrm{pH}$ value of the filtrate could not be determined in this volume condition. Furthermore, over $30 \mathrm{~mL}$ (the $\mathrm{pH}$ value, total $\mathrm{Fe}$ and the $\mathrm{SO}_{4}{ }^{2-}$ of the filtrate can be determined in this volume condition) of the filtrate could be collected from the bottom of the soil columns in treatment 2 on day 10 (3rd batch application, $44 \mathrm{~mL}$ AMD/application), from the columns in treatment 3 on day 5 (2nd batch application, $66 \mathrm{~mL}$ AMD/application), from the columns in treatment 4 on day 5 (2nd batch application, $88 \mathrm{~mL}$ $\mathrm{AMD} /$ application), and from the columns in treatment 5 on day 0 (1st batch application, $110 \mathrm{~mL}$ AMD/application). 
Although the calcareous soil became gradually acidified from the addition of AMD, the soil showed a strong acid buffering ability. For example, the $\mathrm{pH}$ of the filtrate that was collected from the bottom of the soil columns in treatments 1, 2, 3, 4, and 5 at 132 days were 7.64, 7.64, 7.17, 6.40, and 6.40, respectively. In short, during the entire experiment, 20 batches of the applications of the simulated AMD (with pH 2.22-2.49) totaling $440 \mathrm{~mL}$ (treatment 1) to $2200 \mathrm{~mL}$ (treatment 5) were added to $\sim 380 \mathrm{~g}$ of calcareous soil, yet the $\mathrm{pH}$ of the filtrate that was collected from the columns only decreased from 7.81 to 6.40. In fact, in a previous study, we confirmed that the $\mathrm{pH}$ of the filtrate from the calcareous soil that was used in this study was close to the initial $\mathrm{pH}$ of AMD when the amount of AMD added was 10 times the quantity of the soil. During the current experiment, it was observed that a large amount of bubbles were generated at the surface of each soil column when AMD was added. This phenomenon may be attributed to the chemical reaction between calcium carbonate $\left(\mathrm{CaCO}_{3}\right)$ in the calcareous brown soil and the $\mathrm{H}^{+}$and $\mathrm{SO}_{4}{ }^{2-}$ in the simulated $\mathrm{AMD}$, releasing carbon dioxide $\left(\mathrm{CO}_{2}\right)$ according to the following reaction:

$$
\mathrm{CaCO}_{3}+2 \mathrm{H}^{+}+\mathrm{SO}_{4}^{2-} \rightarrow \mathrm{CaSO}_{4}+\mathrm{CO}_{2}+\mathrm{H}_{2} \mathrm{O}
$$

\subsection{Retention Efficiency of the Calcareous Soil for Total $\mathrm{Fe}, \mathrm{SO}_{4}{ }^{2-}$, and $\mathrm{Cu}^{2+}$ Ions during AMD Application}

To better evaluate the migration behavior of $\mathrm{Fe}$ ions and $\mathrm{SO}_{4}{ }^{2-}$ ions in calcareous brown soil resulting from the AMD batch applications, the concentrations of the total $\mathrm{Fe}$ and $\mathrm{SO}_{4}{ }^{2-}$ ions in the filtrate that was collected from the bottom of the different soil columns were determined (Figure 3).

The initial concentration of total Fe ions in the different batches of AMD ranged from $7464.61 \mathrm{mg} / \mathrm{L}$ to $9328.02 \mathrm{mg} / \mathrm{L}$. As can be seen in Figure 3a, the amount of total Fe ions in the filtrate that was collected from the bottom of different soil columns was in the range of 0-30.92 mg/L. In other words, the total Fe ions in AMD were nearly completely removed when the simulated AMD migrated vertically through $20 \mathrm{~cm}$ of calcareous brown soil. For example, in the 20th batch application, the retention efficiency for total Fe ions reached 99.99\%, 99.91\%, 99.98\%, 99.95\%, and 99.90\% when $22 \mathrm{~mL}, 44 \mathrm{~mL}, 66 \mathrm{~mL}, 88 \mathrm{~mL}$, and $110 \mathrm{~mL}$, respectively, of AMD (pH 2.39, total Fe ions concentration $8542.06 \mathrm{mg} / \mathrm{L}$ ) was added to the different soil columns. The efficient retention of total Fe in calcareous soil may mainly be due to Fe precipitation when the soil was polluted by AMD. According to Brittons [38], $\mathrm{Fe}^{3+}$ hydroxide precipitates at $\mathrm{pH} 3$. During the system, $\mathrm{pH}$ changes from $\sim 3$ to $\sim 7, \mathrm{Fe}^{3+}$ may precipitate in the form of $\mathrm{Fe}\left(\mathrm{OH}_{3}\right)$, schwertmannite, or ferrihydrite, etc. [39,40]. Qiao et al. [32] reported that the total Fe removal efficiency reached $99.8 \%$ when AMD ( $\mathrm{pH} 1.44$, total Fe concentration $\sim 3000 \mathrm{mg} / \mathrm{L}$ ) was neutralized by $\mathrm{CaO}$ to $\mathrm{pH} \sim 7$.

The initial concentrations of $\mathrm{SO}_{4}{ }^{2-}$ ions in the different batches of simulated AMD ranged from $19,542.25 \mathrm{mg} / \mathrm{L}$ to $35,035.21 \mathrm{mg} / \mathrm{L}$. Figure $3 \mathrm{~b}$ shows the concentration of $\mathrm{SO}_{4}{ }^{2-}$ ions in the filtrate that was collected from the different soil columns. For treatments $1,2,3,4$, and 5, the $\mathrm{SO}_{4}{ }^{2-}$ ion retention efficiency reached $90.08-94.67 \%, 85.43-93.18 \%, 86.16-93.57 \%, 82.07-91.97 \%$, and $81.67-92.88 \%$, respectively, during 20 batches of AMD applications. For example, in the 20th application, the $\mathrm{SO}_{4}{ }^{2-}$ ion retention efficiency were $93.59 \%, 85.71 \%, 86.16 \%, 82.63 \%$, and $81.67 \%$ in treatments $1,2,3,4$, and 5 , respectively. The efficiency of retaining Fe ions in calcareous soil was better than that $\mathrm{SO}_{4}{ }^{2-}$ ions. The vertical migration of $\mathrm{SO}_{4}{ }^{2-}$ should be given sufficient attention when AMD contaminates calcareous soil.

Based on Equation 1, the premise of the effective attenuation of $\mathrm{SO}_{4}{ }^{2-}$ ions during vertical migration of AMD through calcareous soil is mainly that $\mathrm{CaCO}_{3}$ reacts with $\mathrm{H}^{+}$ions to produce $\mathrm{Ca}^{2+}$, which combines with $\mathrm{SO}_{4}{ }^{2-}$ ions and is synthesized to $\mathrm{CaSO}_{4}$. Komnitsas et al. [39] found that when limestone was used as a neutralizer for AMD treatment, the removal of sulfates from the AMD was promoted by the release of calcium ions due to the dissolution of limestone and the subsequent precipitation of gypsum. However, in the current study, the $\mathrm{pH}$ of the filtrate that was collected from the different treatments changed from 6.40 to 7.81 after 20 batches of AMD applications (Figure 2). Therefore, the dissolution capacity of $\mathrm{H}^{+}$on $\mathrm{CaCO}_{3}$ was limited when $\mathrm{pH}$ was in the range of $6.40-7.81$, 
which may be the main reason for the relatively low $\mathrm{SO}_{4}{ }^{2-}$ ion retention efficiency in this experiment. Of course, other chemicals (such as $\mathrm{MgCO}_{3}, \mathrm{Al}_{2} \mathrm{O}_{3}$, and $\mathrm{Fe}_{2} \mathrm{O}_{3}$, etc.) in calcareous soil can also react with $\mathrm{H}^{+}$, which further reduces the $\mathrm{H}^{+}$ions concentration which, in turn, further reduces the release of $\mathrm{Ca}^{2+}$.

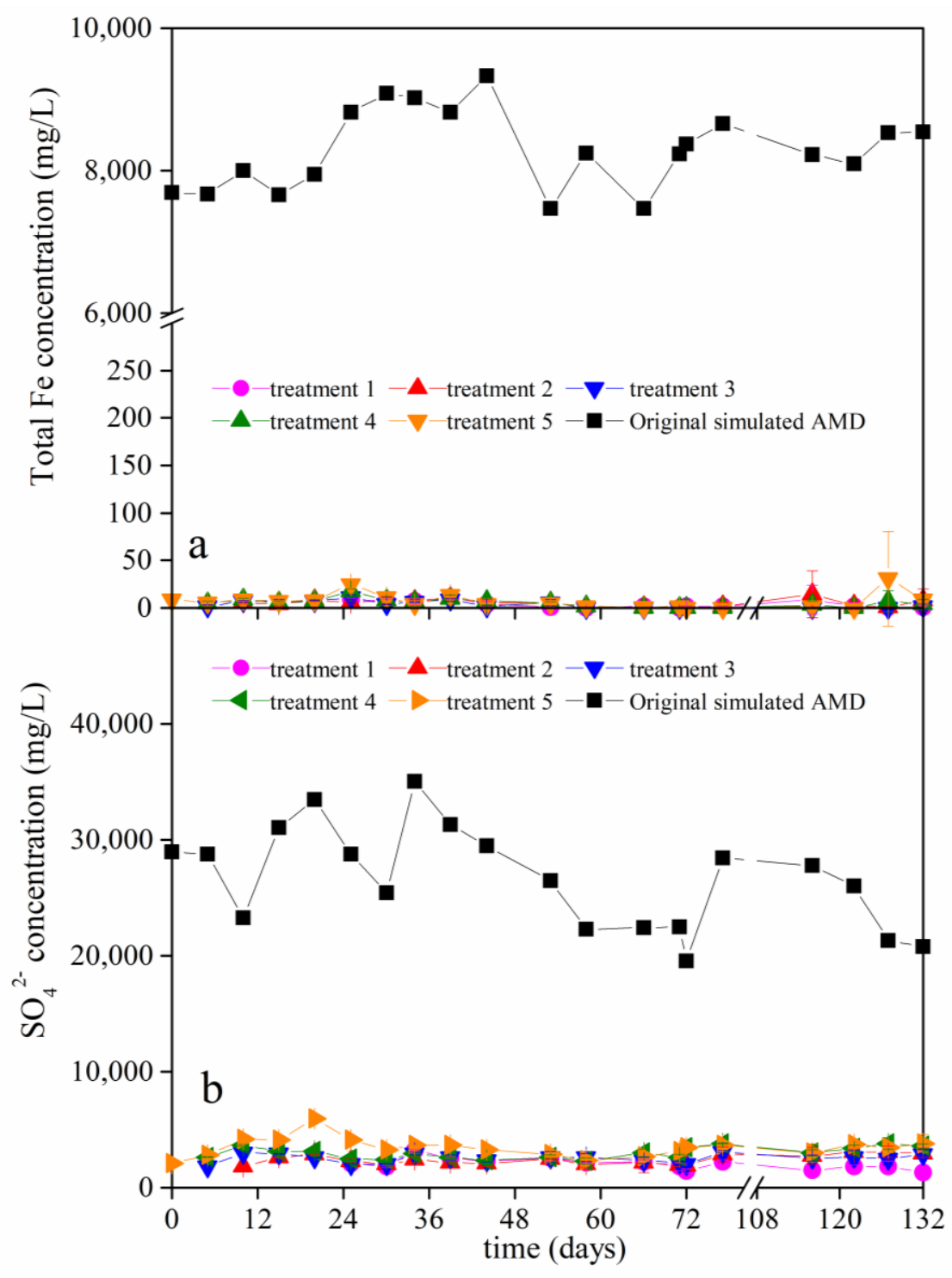

Figure 3. The concentrations of the (a) total Fe ions and (b) $\mathrm{SO}_{4}{ }^{2-}$ in the filtrate that was collected from the bottom of the soil columns in the different treatments. (Treatments 1, 2, 3, 4, and 5 represent the addition of $22,44,66,88$, and $110 \mathrm{~mL}$, respectively, of simulated acid mine drainage (AMD) that was added to the soil columns at each application).

AMD is characterized by a low $\mathrm{pH}$, high concentrations of $\mathrm{SO}_{4}{ }^{2-}$ ions and total $\mathrm{Fe}$, and various concentrations of different metals such as $\mathrm{Cu}, \mathrm{Al}$, and $\mathrm{Ni}$. The retention efficiency of calcareous soil for heavy metals was investigated using $\mathrm{Cu}$ as the representative pollutant. The $\mathrm{Cu}$ retention efficiency in the different treatments at applications 6, 9, 12, 15, 18, and 20 are shown in Figure 4. 


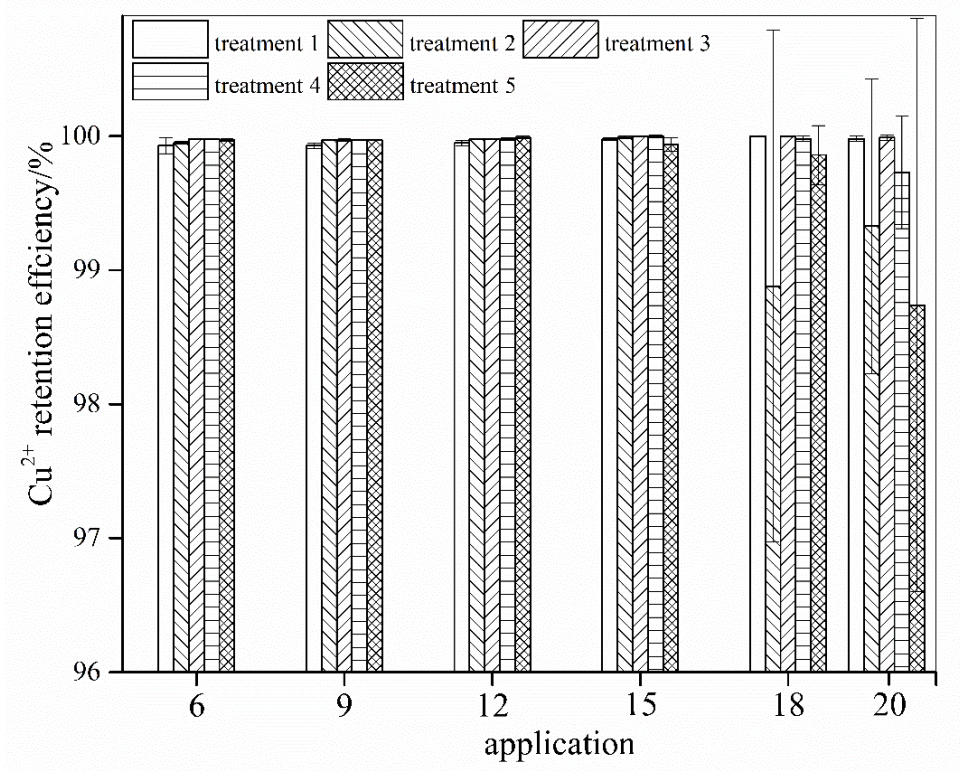

Figure 4. The $\mathrm{Cu}^{2+}$ retention efficiency during the addition of simulated acid mine drainage (AMD) into calcareous soil. (Treatments 1, 2, 3, 4, and 5 represent the addition of 22, 44, 66, 88, and $110 \mathrm{~mL}$, respectively of simulated AMD into the soil columns at each application).

Except in treatment $5\left(110 \mathrm{~mL}\right.$ AMD/application) at application $20, \mathrm{Cu}^{2+}$ was almost completely retained (retention efficiency above $\sim 99 \%$ ) by the soil in all of the treatments and all of the AMD applications within the treatments. The $\mathrm{Cu}^{2+}$ concentration reached $0.62 \mathrm{mg} / \mathrm{L}$ (retention efficiency was $98.7 \%$ ) in the filtrate ( $\mathrm{pH} 6.40)$ that was collected from the soil columns in treatment $5(110 \mathrm{~mL}$ AMD/application; $\mathrm{pH} 2.39 ; \mathrm{Cu}^{2+}$ concentration: $49.27 \mathrm{mg} / \mathrm{L}$ ) at application 20. According to Britton (1956) [38], $\mathrm{Cu}$ hydroxide precipitates at $\mathrm{pH} \sim 5.3$. Gitari et al. [40] examined fly ash-treated AMD and observed that $>75 \%$ of the total $\mathrm{Cu}$ precipitated out of the solution when the system $\mathrm{pH}>5.5$. In addition, ferrihydrite or schwertmannite that is produced from $\mathrm{Fe}^{3+}$ hydrolysis when AMD contaminates calcareous soil can adsorb $\mathrm{Cu}^{2+}[41,42]$, and the organic matter in calcareous soil can complex $\mathrm{Cu}^{2+}[43]$. However, the $\mathrm{Cu}^{2+}$ that precipitated at a high $\mathrm{pH}$ is probably the main reason for the efficient retention of $\mathrm{Cu}^{2+}$ by the soil in this study.

\subsection{Distribution of $\mathrm{H}^{+}, \mathrm{Fe}, \mathrm{S}, \mathrm{Cu}$, and $\mathrm{Ca}$ in AMD-Polluted Calcareous Soil}

To better investigate the migration behavior in calcareous soil of typical pollutants $\left(\mathrm{H}^{+}, \mathrm{Fe}, \mathrm{S}\right.$, and $\mathrm{Cu}$ ) from $\mathrm{AMD}$, as well as a characteristic element (Ca), the soil columns in treatments $1-5$ were separated at the middle of each column after 20 batches of applications of AMD and were analyzed. The $\mathrm{pH}$ (Figure $5 \mathrm{a}$ ) of the soil ${ }_{0-10 \mathrm{~cm}}$ samples was lower than the $\mathrm{pH}$ of the soil $1_{10-20 \mathrm{~cm}}$ samples in all of the treatments. Compared with the initial soil $\mathrm{pH}(8.24)$, the $\mathrm{pH}$ of the $\mathrm{soil}_{0-10 \mathrm{~cm}} / \mathrm{soil}_{10-20 \mathrm{~cm}}$ samples in treatments 1-5 were 7.51/7.91, 6.39/7.57, 4.10/7.39, 4.08/6.24, and 3.65/6.21, respectively. There was a significant negative correlation between the amount of AMD added and the $\mathrm{pH}$ of the soil $_{0-10 \mathrm{~cm}}$ samples in all of the treatments $\left(R^{2}=0.868\right)$ as well as the $\mathrm{pH}$ of the soil $10-20 \mathrm{~cm}$ samples in all of the treatments $\left(R^{2}=0.900\right)$.

The distribution of $\mathrm{H}^{+}$at different locations can be indirectly represented by the $\mathrm{pH}$ value. In treatment 1 , the $\mathrm{pH}$ of the soil changed from 8.24 to 7.51 in the soil $1_{0-10 \mathrm{~cm}}$ sample and from 8.24 to 7.91 in the soil $10-20 \mathrm{~cm}$ sample. Therefore, the distribution of $\mathrm{H}^{+}$ions in the soil $1_{0-10 \mathrm{~cm}}$ sample was 3.84 times that of the soil $10-20 \mathrm{~cm}$ sample. Similarly, the distribution of $\mathrm{H}^{+}$ions in the soil ${ }_{0-10 \mathrm{~cm}}$ samples was 18.98, 2270.41, 145.99, and 366.49 times that in the soil $1_{10-20 \mathrm{~cm}}$ samples in treatments $2,3,4$, and 5, respectively. Notably, the retention efficiency for $\mathrm{H}^{+}$ions in the soil $1_{0-10 \mathrm{~cm}}$ samples reached 2270.41 times more than in the soil $1_{10-20 \mathrm{~cm}}$ samples in treatment 3 ( $66 \mathrm{~mL}$ AMD/application). 
Yang et al. [5] studied the variation of $\mathrm{pH}$ in paddy red soil profiles along the Hengshi River that have been polluted by AMD from the Dabaoshan mining area in South China and found that the $\mathrm{pH}$ slightly increased from 4.75 in the soil at a $0-10 \mathrm{~cm}$ depth, and to 5.00 in the soil at a $10-20 \mathrm{~cm}$ depth. Thus, compared to that in the red soil, the interception of $\mathrm{H}^{+}$in calcareous soil exhibits more distinct "layering".
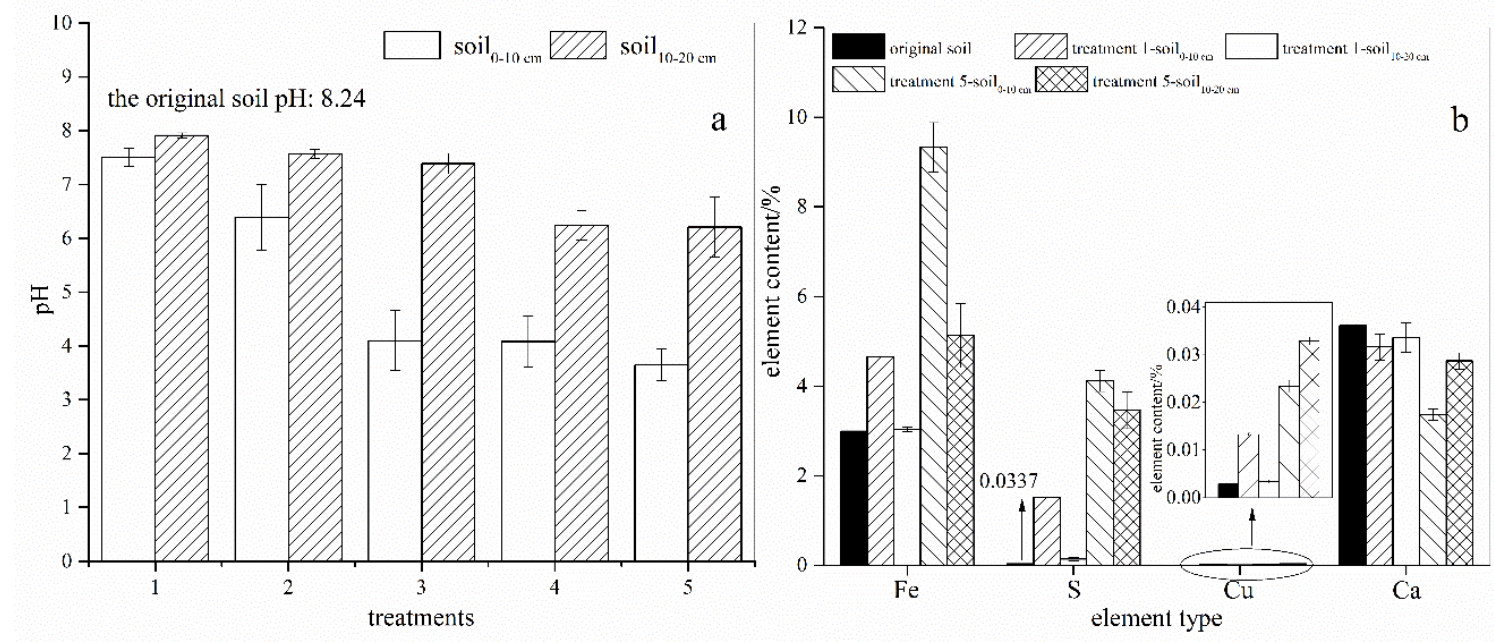

Figure 5. (a) The $\mathrm{pH},(\mathbf{b}) \mathrm{Fe}, \mathrm{S}, \mathrm{Cu}$, and $\mathrm{Ca}$ distributed in the calcareous soil $(0-10 \mathrm{~cm}$ and $10-20 \mathrm{~cm}$ depths) that was contaminated by simulated acid mine drainage (AMD). (Treatments 1 and 5 represent the addition of 22 and $110 \mathrm{~mL}$, respectively, of simulated AMD to the soil columns at each application).

The $\mathrm{Fe}, \mathrm{S}, \mathrm{Cu}$, and $\mathrm{Ca}$ concentrations in the soil $_{0-10 \mathrm{~cm}}$ and soil $10-20 \mathrm{~cm}$ samples from treatment 1 and treatment 5 were analyzed and the results are shown in Figure $5 \mathrm{~b}$. The concentration of Fe in the original soil was $2.99 \%$. After 20 batches of applications of simulated AMD, the concentrations of Fe in the soil ${ }_{0-10 \mathrm{~cm}}$ and soil $10-20 \mathrm{~cm}$ samples were $4.65 \%$ and $3.03 \%$, respectively (treatment 1 ), and $9.33 \%$ and $5.13 \%$, respectively (treatment 5). Thus, in treatment $1,97.6 \%$ of the total Fe was distributed in the soil $_{0-10 \mathrm{~cm}}$ sample and $2.4 \%$ was in the soil $10-20 \mathrm{~cm}$ sample. However, in treatment $5,74.8 \%$ of the total Fe was distributed in the soil ${ }_{0-10 \mathrm{~cm}}$ sample and $25.2 \%$ in the soil $10-20 \mathrm{~cm}$ sample. These results indicated that the distribution of Fe in calcareous soil gradually moved downward through the soil profile as the volume of AMD in the batches of the applications increased.

In treatment $1,93.1 \%$ of the elemental $\mathrm{S}$ was distributed in the soil $0-10 \mathrm{~cm}$ sample and $6.9 \%$ was in the soil $1_{10-20 \mathrm{~cm}}$ sample. In treatment 5, the corresponding proportions were $54.3 \%$ and $45.7 \%$. These results support the conclusion that compared with elemental $\mathrm{Fe}$, elemental $\mathrm{S}$ is more likely to move vertically in calcareous soil that has been contaminated by AMD. Fe ions can precipitate rapidly (almost immediately) and prevent the further downward migration of Fe. However, the migration of $S$ is affected by $\mathrm{CaCO}_{3}$ dissolution and $\mathrm{CaSO}_{4}$ synthesis, which may not occur at the same locations in the soil profile when AMD infiltrates into the soil. When $\mathrm{CaCO}_{3}$ dissolves under the influence of $\mathrm{H}^{+}$ ions, $\mathrm{Ca}^{2+}$ migrates downward and combines with $\mathrm{SO}_{4}{ }^{2-}$ during the migration process, which causes elemental $\mathrm{S}$ to move further downward than $\mathrm{Fe}$ in calcareous soil that has been contaminated by AMD. Yang et al. [5] found that $\mathrm{SO}_{4}{ }^{2-}$ can react with $\mathrm{Fe}$ oxides/hydroxides under acidic conditions in red paddy soil. In the current study of calcareous soil, the $\mathrm{SO}_{4}{ }^{2-}$ that was retained by Fe oxides/hydroxides was not significant because the elemental $\mathrm{S}$ and elemental $\mathrm{Fe}$ migration rates were not similar.

In treatment $1,95.4 \%$ of the elemental $\mathrm{Cu}$ was distributed in the soil $1_{0-10 \mathrm{~cm}}$ sample $(\mathrm{pH} 7.51)$ and $4.6 \%$ was in the soil $1_{10-20 \mathrm{~cm}}$ sample $(\mathrm{pH} 7.91)$ after 20 applications of simulated AMD. In treatment $5,40.6 \%$ of the elemental $\mathrm{Cu}$ was distributed in the soil $0-10 \mathrm{~cm}$ sample $(\mathrm{pH} 3.65)$ and $59.4 \%$ was in the soil $10-20 \mathrm{~cm}$ sample ( $\mathrm{pH}$ 6.21) after 20 batches of applications of AMD. Cu can form hydroxide precipitates at $\mathrm{pH} \sim 5.3$ [38]. Therefore, the retention capacity of $\mathrm{Cu}$ was reduced in the soil $1_{0-10 \mathrm{~cm}}$ sample 
in treatment 5 because the 20 batches of applications of large doses of AMD (110 mL/application) caused the $\mathrm{pH}$ to decrease to 3.65. Thus, as shown in previous studies, soil $\mathrm{pH}$ has a great influence on the migration of elemental $\mathrm{Cu}$.

Elemental Ca is a characteristic element in calcareous soil. In treatment 1 , compared with that in the original soil, the Ca content in the soil $0-10 \mathrm{~cm}$ sample decreased by $8.97 \%$ and that of the $50 \mathrm{l}_{10-20 \mathrm{~cm}}$ sample decreased by $5.05 \%$. Comparable changes in treatment 5 were decreases of $37.2 \%$ and $14.8 \%$ in the soil ${ }_{0-10 \mathrm{~cm}}$ and soil $10-20 \mathrm{~cm}$ samples, respectively. Notably, the decrease in the Ca content may have been caused by the leaching of $\mathrm{Ca}^{2+}$ or by the conversion of $\mathrm{CaCO}_{3}$ to $\mathrm{CaSO}_{4}$ (and subsequent leaching) when the calcareous soil was subjected to the simulated AMD. For example, the Ca content decreases by $26.5 \%$ when 1 unit of $\mathrm{CaCO}_{3}$ is transformed to $\mathrm{CaSO}_{4}$. Therefore, the $\mathrm{Ca}$ in the soil $\mathrm{l}_{0-10 \mathrm{~cm}}$ sample in treatment 5 may have been removed by leaching because the Ca content in this soil layer decreased by $37.2 \%$. This phenomenon provides corroborating evidence for the elemental $\mathrm{S}$ migration behavior in soil. In other words, in calcareous soil that has been affected by AMD, elemental Ca can enter the lower soil layer from the surface by leaching and binding with $\mathrm{SO}_{4}{ }^{2-}$ in the lower layer. This interaction forms $\mathrm{CaSO}_{4}$, which makes the vertical migration rate of elemental S significantly higher than that of elemental Fe.

\subsection{Calcareous Soil Mineral Phase before and after AMD Contamination}

The mineral phase of inorganic soil particles can be explored using XRD technology [44]. In this study, the XRD patterns of the original soil and the AMD-polluted soil were examined. The soil ${ }_{0-10 \mathrm{~cm}}$ and soil $10-20 \mathrm{~cm}$ samples from treatments 1 and 5 were used as examples and are shown in Figure 6 . According to the Joint Committee on Power Diffraction Standards data files [45] cards No. 46-1045 and 47-1743, the patterns in Figure 6 indicate that the dominant substances in the original soil were $\mathrm{SiO}_{2}$ (characteristic peak in XRD patterns at $2 \theta=26.64^{\circ}$ and $20.86^{\circ}$ ) and $\mathrm{CaCO}_{3}$ (calcite, characteristic peak in XRD patterns at $2 \theta=29.40^{\circ}$ ).

Although the original soil also contained other oxides $\left(\mathrm{Fe}_{2} \mathrm{O}_{3}, \mathrm{Al}_{2} \mathrm{O}_{3}\right.$, etc.), organic matter, and other material, the characteristic diffraction peaks of these substance did not exhibit an obvious XRD pattern because the $\mathrm{SiO}_{2}$ and $\mathrm{CaCO}_{3}$ accounted for such a large proportion of the calcareous soil $[46,47]$. After the calcareous soil was subjected to AMD, the characteristic peak $\left(2 \theta=29.40^{\circ}\right)$ of $\mathrm{CaCO}_{3}$ could not be observed in the soil ${ }_{0-10 \mathrm{~cm}}$ samples from either treatment 1 or treatment 5 , nor in the soil $1_{10-20 \mathrm{~cm}}$ sample from treatment 5 . By comparing the XRD patterns of these treatments to JCPDS card (No. 33-0311) and the results from previous research, an interesting peak $\left(2 \theta=11.60^{\circ}\right)$ characteristic of $\mathrm{CaSO}_{4} \cdot 2 \mathrm{H}_{2} \mathrm{O}$ was observed in the soil ${ }_{0-10 \mathrm{~cm}}$ samples from treatments 1 and 5 and in the soil $10-20 \mathrm{~cm}$ sample from treatment 5 . This result provided great support for the retention capacity of soil for elemental S, as shown in Figure 5. Notably, the characteristic peak $\left(2 \theta=11.60^{\circ}\right)$ of $\mathrm{CaSO}_{4} \cdot 2 \mathrm{H}_{2} \mathrm{O}$ was not observed in the XRD pattern for the soil $1_{10-20 \mathrm{~cm}}$ sample from treatment 1 because elemental S barely accumulated in this soil layer. Moreover, the XRD patterns that are shown in Figure 6 directly indicate that the transformation of $\mathrm{CaCO}_{3}$ to $\mathrm{CaSO}_{4}$ did actually occur in the calcareous soil that was contaminated by AMD.

SEM images of calcareous soil before and after being subjected to AMD are shown in Figure 7. The SEM image of the original calcareous soil (Figure 7a) shows that the mineral morphology of the calcareous soil was a mixture of crystal and amorphous materials. The energy dispersive X-ray spectroscopy (EDS) spectrum of the representative particle that is identified in Figure 7a showed that the main elements in the original calcareous soil were $\mathrm{O}(55.36 \mathrm{wt} \%), \mathrm{Si}(21.88 \mathrm{wt} \%), \mathrm{Al}(5.44 \mathrm{wt} \%)$, $\mathrm{Ca}(4.86 \mathrm{wt} \%), \mathrm{Fe}(4.82 \mathrm{wt} \%)$, and $\mathrm{K}(1.78 \mathrm{wt} \%)$ (Figure $7 \mathrm{~b})$. These data suggest that the main chemical components in the original soil were $\mathrm{SiO}_{2}, \mathrm{Al}_{2} \mathrm{O}_{3}, \mathrm{CaCO}_{3}, \mathrm{Fe}_{2} \mathrm{O}_{3}, \mathrm{~K}_{2} \mathrm{O}$, etc. However, the SEM image of the AMD-contaminated soil (Figure $7 \mathrm{c}$ ) shows the rod-shaped morphology of $\mathrm{CaSO}_{4} \cdot 2 \mathrm{H}_{2} \mathrm{O}$ in the soil $l_{0-10 \mathrm{~cm}}$ sample from treatment 5 . Furthermore, the chemical composition of $\mathrm{CaSO}_{4} \cdot 2 \mathrm{H}_{2} \mathrm{O}$ was confirmed by the EDS patterns that are shown in Figure 7d. Of course, the elements $\mathrm{Si}, \mathrm{Al}, \mathrm{Fe}$, and $\mathrm{K}$ could also exist in other particles in the AMD-contaminated soil (Figure 7e). 


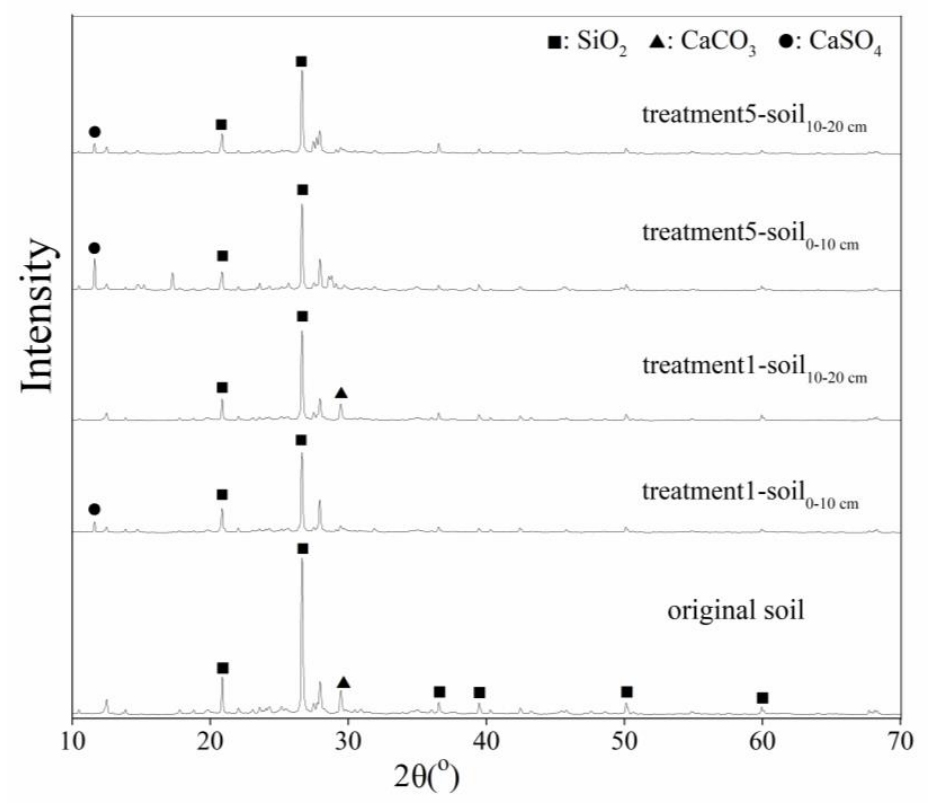

Figure 6. X-ray diffraction patterns for calcareous soil before (original soil) and after the addition of simulated acid mine drainage (AMD). (Treatments 1 and 5 represent the addition of 22 and $110 \mathrm{~mL}$, respectively, of simulated AMD to the soil columns at each application. The soil samples are from $0-10 \mathrm{~cm}$ to $10-20 \mathrm{~cm}$ depths).

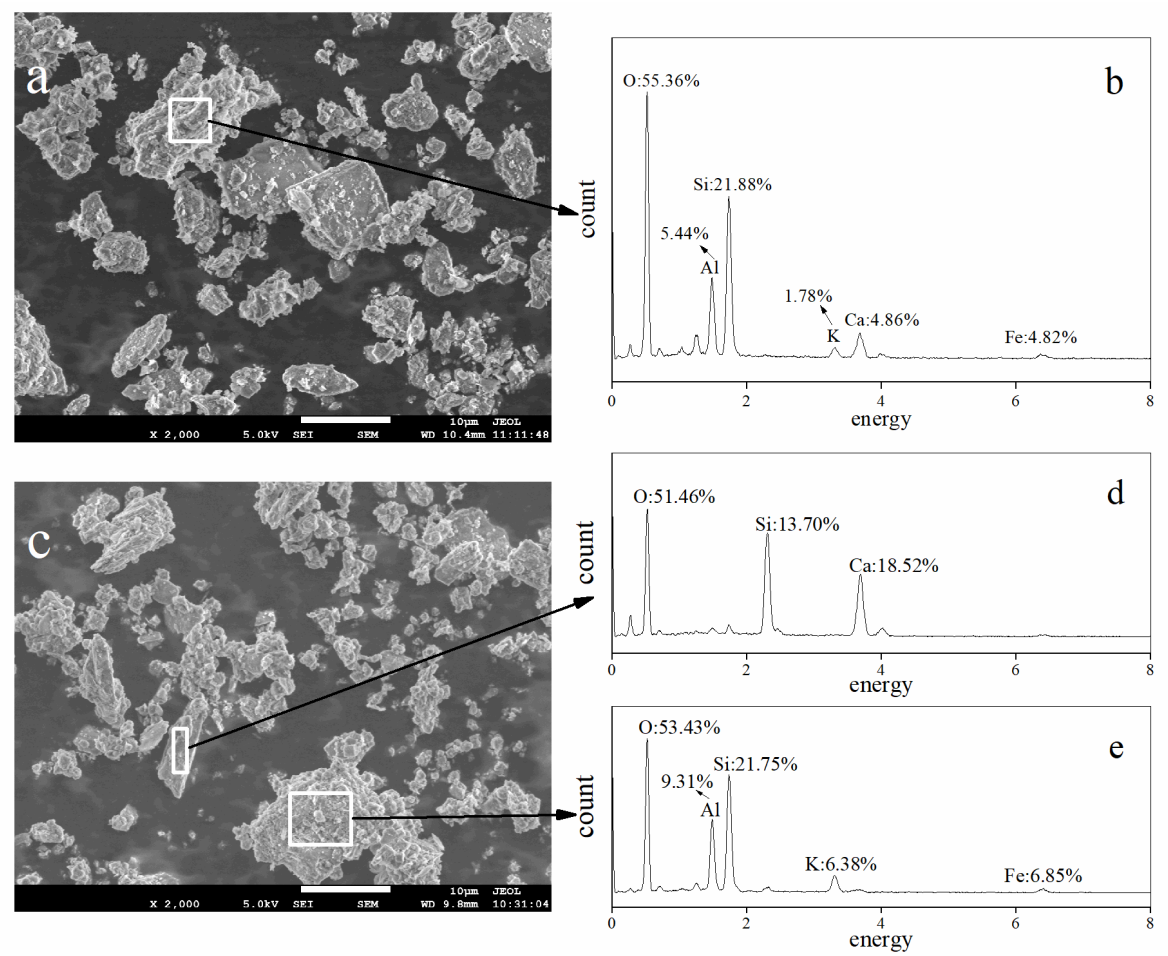

Figure 7. Scanning electron microscopy (SEM) images and energy dispersive X-ray spectroscopy (EDS) spectra of the calcareous soil before and after the addition of simulated acid mine drainage (AMD). (a) SEM of the original soil; (b) EDS of the particle marked with a square in 7 (a); (c) $\mathrm{SEM}$ of soil ${ }_{0-10 \mathrm{~cm}}$ in treatment 5 (110 $\mathrm{mL} \mathrm{AMD/application);} \mathrm{(d)} \mathrm{EDS} \mathrm{of} \mathrm{the} \mathrm{particle} \mathrm{marked} \mathrm{with} \mathrm{a} \mathrm{narrow} \mathrm{rectangle} \mathrm{in}$ 7 (c); (e) EDS of the particle marked with a square in 7 (c). 


\section{Conclusions and Prospects}

Shanxi, a province in the northern part of China, is rich in mineral resources, and AMD is a typical contaminant in mining areas in Shanxi. The dominant type of soil in Shanxi is calcareous soil. To our knowledge, this study is the first to address the migration behavior of AMD pollutants, such as $\mathrm{H}^{+}$, $\mathrm{Fe}, \mathrm{S}$, and heavy metals (using $\mathrm{Cu}$ as an example) in calcareous soil in the Shanxi area. The results described in Section 3 support the following conclusions: Calcareous soil has a great $\mathrm{pH}$ buffering effect on AMD. This effect is significantly and negatively correlated with the amount of AMD added, as is indicated by $\mathrm{pH}$ changes in the top $0-20 \mathrm{~cm}$ layer of the soil. In the calcareous soil that is affected by $\mathrm{AMD}, \mathrm{CaCO}_{3}$ is transformed into $\mathrm{CaSO}_{4}$. Almost all Fe ions from AMD can be retained in the 0-20 cm surface soil and more than $80 \%$ of $\mathrm{SO}_{4}{ }^{2-}$ can be retained in this layer. Thus, the retention efficiency of calcareous soil is greater for $\mathrm{Fe}$ than for $\mathrm{SO}_{4}{ }^{2-}$. The vertical migration of elemental $\mathrm{S}$ in calcareous soil is obviously greater than that of elemental Fe. Elemental $\mathrm{Cu}$, a representative of other heavy metals that are often contained in AMD, can be totally retained by calcareous soil in some conditions. However, the $\mathrm{Cu}$ has a tendency to migrate downward with the gradual acidification of the upper soil profile.

The outcomes of this study are valuable for understanding the pollution of calcareous soil by AMD. Calcareous soil had a strong buffer effect on AMD acidity due to it containing a large amount of calcium carbonate, which resulted in a large number of AMD pollutants' (Fe, S, and heavy metals) vertical migration slowly, and mainly accumulated on the surface $(0-20 \mathrm{~cm})$ of the soil. However, the vertical migration of sulfates is faster than that of iron, which increases the possibility of groundwater sulfate-contamination. The removal of sulfate from AMD is our team's main future research direction.

Author Contributions: Conceptualization, F.L., L.Z.; Investigation, F.L., X.Q. and J.Z.; Data Curation, X.Q. and J.Z.; Writing-Original Draft Preparation, F.L., X.Q., L.Z.; Supervision, F.L.; Project Administration, F.L., L.Z.; Funding Acquisition, F.L. and L.Z.

Funding: This research was funded by the National Natural Science Foundation of China, grant number [21637003, 21407102], the Program for the Top Young Innovative Talents of Shanxi Agricultural University, grant number [TYIT 201405], and the Innovation Project of Post-graduate Education in Shanxi Province, China, grant number [2018SY035].

Acknowledgments: We thank the Analytical Instrumentation Center, Institute of Coal Chemistry, Chinese Academy of Sciences, China, and the Sanshui Experimental Testing Center, Shanxi province, China for their support. We also would like to thank the anonymous reviewer for their useful and constructive suggestions.

Conflicts of Interest: The authors declare no conflict of interest.

\section{References}

1. Wang, Z.H.; Sun, J.W. Analysis of interregional industry linkage and economic distance in China: Evidence from the mining industry. Appl. Econ. 2017, 49, 606-617. [CrossRef]

2. Liu, F.W.; Zhou, J.; Zhou, L.X.; Zhang, S.S.; Liu, L.L.; Wang, M. Effect of neutralized solid waste generated in lime neutralization on the ferrous ion bio-oxidation process during acid mine drainage. J. Hazard. Mater. 2015, 299, 404-411. [CrossRef] [PubMed]

3. Li, L.; Lei, Y.L.; Xu, Q.; Wu, S.M.; Yan, D.; Chen, J.B. Crowding-out effect of coal industry investment in coal mining area: Taking Shanxi province in China as a case. Environ. Sci. Pollut. Res. 2017, 24, 23290-23298. [CrossRef] [PubMed]

4. Liao, J.B.; Wen, Z.W.; Ru, X.; Chen, J.D.; Wu, H.Z.; Wei, C.H. Distribution and migration of heavy metals in soil and crops affected by acid mine drainage: Public health implications in Guangdong Province, China. Ecotoxicol. Environ. Saf. 2016, 124, 460-469. [CrossRef] [PubMed]

5. Yang, D.J.; Bian, Z.F.; Lei, S.G. Impact on soil physical qualities by the subsidence of coal mining: A case study in Western China. Environ. Earth Sci. 2016, 75, 652. [CrossRef]

6. Smart, D.; Callery, S.; Courtney, R. The Potential for Waste-Derived Materials to Form Soil Covers for the Restoration of Mine Tailings in Ireland. Land Degrad. Dev. 2016, 27, 542-549. [CrossRef] 
7. Cheng, W.M.; Nie, W.; Pan, G.; Cao, S.; Zhang, X.H. Study and prevention on the diffusion rule of dust pollution in the coal mine whole-rock fully mechanized workface. Appl. Mech. Mater. 2013, 246-247, 608-613. [CrossRef]

8. Galhardi, J.A.; Bonotto, D.M. Hydrogeochemical features of surface water and groundwater contaminated with acid mine drainage (AMD) in coal mining areas: A case study in southern Brazil. Environ. Earth Sci. 2016, 23, 18911-18927. [CrossRef] [PubMed]

9. Miguel, M.G.; Barreto, R.P.; Pereira, S.Y. Study of a tropical soil in order to use it to retain aluminum, iron, manganese and fluoride from acid mine drainage. J. Environ. Manag. 2017, 204, 563-570. [CrossRef] [PubMed]

10. Ouyang, Y.T.; Liu, Y.; Zhu, R.L.; Ge, F.; Xu, T.Y.; Luo, Z.; Liang, L.B. Pyrite oxidation inhibition by organosilane coatings for acid mine drainage control. Miner. Eng. 2015, 72, 57-64. [CrossRef]

11. Prasad, D.; Henry, J.G. Removal of sulphates acidity and iron from acid mine drainage in a bench scale biochemical treatment system. Environ. Technol. 2009, 30, 151-160. [CrossRef] [PubMed]

12. Kwon, H.W.; Kim, J.J.; Ha, D.W.; Kim, Y.H. Formation of iron oxides from acid mine drainage and magnetic separation of the heavy metals adsorbed iron oxides. Prog. Supercon. Cryogen. 2016, 18, 28-32. [CrossRef]

13. Gaikwad, R.W. Review on removal of heavy metals from acid mine drainage. Appl. Ecol. Environ. Res. 2008, 6, 81-98. [CrossRef]

14. Sun, M.; Xiao, T.F.; Ning, Z.P.; Xiao, E.Z.; Sun, W.M. Microbial community analysis in rice paddy soils irrigated by acid mine drainage contaminated water. Appl. Microbiol. Biot. 2015, 99, 2911-2922. [CrossRef] [PubMed]

15. Wang, H.; Zeng, Y.F.; Guo, C.L.; Bao, Y.P.; Lu, G.N.; Reinfelder, J.R.; Dang, Z. Bacterial, archaeal, and fungal community responses to acid mine drainage-laden pollution in a rice paddy soil ecosystem. Sci. Total Environ. 2018, 616-617, 107-116. [CrossRef] [PubMed]

16. Desoeuvre, A.; Casiot, C.; Héry, M. Diversity and distribution of arsenic-related genes along a pollution gradient in a river affected by acid mine drainage. Microb. Ecol. 2015, 71, 672-685. [CrossRef] [PubMed]

17. Nieto, J.M.; Sarmiento, A.M.; Olías, M.; Canovas, C.R.; Riba, I.; Kalman, J.; Delvalls, T.A. Acid mine drainage pollution in the Tinto and Odiel rivers (Iberian Pyrite Belt, SW Spain) and bioavailability of the transported metals to the Huelva Estuary. Environ. Int. 2007, 33, 445-455. [CrossRef] [PubMed]

18. Singovszka, E.; Balintova, M.; Demcak, S.; Pavlikova, P. Metal pollution indices of bottom sediment and surface water affected by acid mine drainage. Metals 2017, 7, 284. [CrossRef]

19. Karimian, N.; Johnston, S.G.; Burton, E.D. Acidity generation accompanying iron and sulfur transformations during drought simulation of freshwater re-flooded acid sulfate soils. Geoderma 2017, 285, 117-131. [CrossRef]

20. Karimian, N.; Johnston, S.G.; Burton, E.D. Iron and sulfur cycling in acid sulfate soil wetlands under dynamic redox conditions: A review. Chemosphere 2018, 197, 803-816. [CrossRef] [PubMed]

21. Chen, W.; Zheng, R.; Baade, P.D.; Zhang, S.; Zeng, H.; Bray, F.; Jemal, A.; Yu, X.Q.; He, J. Cancer statistics in China, 2015. CA-Cancer J. Clin. 2016, 66, 115-132. [CrossRef] [PubMed]

22. Li, L.L.; Bellotti, B.; Zhang, R.Z.; Zhang, H.L. Conservation agriculture in rainfed areas of China. In Conservation Agriculture; Springer International Publishing: Cham, Switzerland, 2015; pp. 311-334.

23. Hong, S.M.; Hao, J.M.; Zhou, N.; Chen, L.; Lü, Z.Y. Change of cultivated land and its impact on grain production pattern in Huang-Huai-Hai Plain. Trans. Chin. Soc. Agric. Eng. 2014, 30, 268-277. [CrossRef]

24. Wang, H.; Guo, C.L.; Yang, C.F.; Lu, G.N.; Chen, M.Q.; Dang, Z. Distribution and diversity of bacterial communities and sulphate-reducing bacteria in a paddy soil irrigated with acid mine drainage. J. Appl. Microbiol. 2016, 121, 196-206. [CrossRef] [PubMed]

25. Li, Y.T.; Becquer, T.; Dai, J.; Quantin, C.; Benedetti, M.F. Ion activity and distribution of heavy metals in acid mine drainage polluted subtropical soils. Environ. Pollut. 2009, 157, 1249-1257. [CrossRef] [PubMed]

26. Yang, C.F.; Lu, G.N.; Chen, M.Q.; Xie, Y.Y.; Guo, C.L.; Reinfelder, J.; Yi, X.Y.; Wang, H.; Dang, Z. Spatial and temporal distributions of sulfur species in paddy soils affected by acid mine drainage in Dabaoshan sulfide mining area, South China. Geoderma 2016, 281, 21-29. [CrossRef]

27. Zhao, F.H.; Cong, Z.Y.; Sun, H.F.; Ren, D.Y. The geochemistry of rare earth elements (REE) in acid mine drainage from the Sitai coal mine, Shanxi Province, North China. Int. J. Coal Geol. 2007, 70, 184-192. [CrossRef] 
28. Gao, J.; Ding, J.N.; Kang, J.; Wu, X.L.; Qiu, G.Z. Identification and heavy metal toxicity assessment upon $\mathrm{Fe}^{2+}$-oxidizing ability of Leptospirillum-like bacterium isolated from acid mine drainage. Chin. J. Nonferr. Met. 2011, 21, 220-226. [CrossRef]

29. Xu, X.P.; He, P.; Qiu, S.J.; Pampolino, M.F.; Zhao, S.C.; Johnston, A.M.; Zhou, W. Estimating a new approach of fertilizer recommendation across small-holder farms in China. Field Crop. Res. 2014, 163, 10-17. [CrossRef]

30. Zhang, X.Q.; Wei, D.P.; Li, B.; Ma, Y.B.; Huang, Z.B. The importance of soil solution chemistry to nickel toxicity on barley root elongation. Chem. Speciat. Bioavailab. 2013, 25, 153-164. [CrossRef]

31. Liu, F.W.; Zhou, J.; Zhang, S.S.; Liu, L.L.; Zhou, L.X.; Fan, W.H. Schwertmannite synthesis through ferrous ion chemical oxidation under different $\mathrm{H}_{2} \mathrm{O}_{2}$ supply rates and its removal efficiency for arsenic from contaminated groundwater. PLoS ONE 2015, 10, e0138891. [CrossRef] [PubMed]

32. Qiao, X.X.; Liu, G.L.; Zhou, L.X.; Xu, J.M.; Hao, X.J.; Liu, F.W. Effect of density and nutrition supply of Acidithiobacillus ferroxidans on biological oxidation of pyrite. Acta Sci. Circumst. 2018, 38, 449-456. [CrossRef]

33. Fu, F.L.; Chen, R.M.; Xiong, Y. Application of a novel strategy-coordination polymerization precipitation to the treatment of $\mathrm{Cu}^{2+}$-containing wastewaters. Sep. Purif. Technol. 2006, 52, 388-393. [CrossRef]

34. Qiao, X.X.; Liu, L.L.; Shi, J.; Zhou, L.X.; Guo, Y.H.; Ge, Y.Y.; Fan, W.H.; Liu, F.W. Heating changes bio-schwertmannite microstructure and arsenic(III) removal efficiency. Minerals 2017, 7, 9. [CrossRef]

35. Wang, X.R.; Zhang, F.S.; Nong, Z.X. Mineral phases and release behaviors of As in the process of sintering residues containing As at high temperature. Sci. World J. 2014, 2014, 260504. [CrossRef] [PubMed]

36. Gros, M.; Lorand, J.P.; Bezos, A. Determination of total sulfur contents in the international rock reference material SY-2 and other mafic and ultramafic rocks using an improved scheme of combustion/iodometric titration. Geostand. Geoanal. Res. 2005, 29, 123-130. [CrossRef]

37. Gao, R.M.; Shi, X.D.; Wang, L.; Han, N. Drought Resistance of One-year-old seedlings of Larix principis-rupprechtii. Sci. Silvae Sin. 2015, 51, 148-156. [CrossRef]

38. Brittons, H.T.S. Hydrogen Ions, 4th ed.; Chapman and Hall: London, UK, 1956.

39. Komnitsas, K.; Bartzas, G.; Paspaliaris, I. Efficiency of limestone and red mud barriers: Laboratory column studies. Miner. Eng. 2004, 17, 183-194. [CrossRef]

40. Gitari, W.M.; Petrik, L.F.; Etchebers, O.; Key, D.L.; Okujeni, C. Utilization of fly ash for treatment of coal mines wastewater: Solubility control on major inorganic contaminants. Fuel 2008, 87, 2450-2462. [CrossRef]

41. Moon, E.M.; Peacock, C.L. Adsorption of $\mathrm{Cu}(\mathrm{II})$ to ferrihydrite and ferrihydrite-bacteria composites: Importance of the carboxyl group for $\mathrm{Cu}$ mobility in natural environments. Geochim. Cosmochim. Acta 2012, 92, 203-219. [CrossRef]

42. Liu, F.W.; Bu, Y.S.; Tian, G.J.; Cui, C.H.; Zhou, L.X. Influence of temperature and pH on dissolution behavior of biogenic schwertmannite in acid environment and the adsorption of $\mathrm{Cu}^{2+}$. Acta Sci. Circumst. 2013, 33, 2445-2451. [CrossRef]

43. Sanders, J.R.; McGrath, S.P. Experimental measurements and computer predictions of copper complex formation by soluble soil organic matter. Environ. Pollut. 1988, 49, 63-76. [CrossRef]

44. Liu, F.W.; Zhou, J.; Jin, T.J.; Zhang, S.S.; Liu, L.L. Effect of calcium oxide on the efficiency of ferrous ion oxidation and total iron precipitation during ferrous ion oxidation in simulated acid mine drainage treatment with inoculation of Acidithiobacillus ferrooxidans. Water Sci. Technol. 2016, 73, 1442-1453. [CrossRef] [PubMed]

45. International Center for Diffraction Data, Swarthmore (JCPDS). Mineral Powder Diffraction Files; JCPDS: Swarthmore, PA, USA, 2002.

46. Ström, L.; Qwen, A.G.; Godbold, D.L.; Jones, D.L. Organic acid behaviour in a calcareous soil: Sorption reactions and biodegradation rates. Soil Biol. Biochem. 2001, 33, 2125-2133. [CrossRef]

47. Tao, Z.Y.; Wang, X.K.; Dai, X.X.; Du, J.Z. Adsorption characteristics of 47 elements on a calcareous soil, a red earth and an alumina: A multitracer study. Appl. Radiat. Isot. 2000, 52, 821-829. [CrossRef]

(C) 2018 by the authors. Licensee MDPI, Basel, Switzerland. This article is an open access article distributed under the terms and conditions of the Creative Commons Attribution (CC BY) license (http:/ / creativecommons.org/licenses/by/4.0/). 